J. Clin. Chem. Clin. Biochem.

Vol. 18, 1980, pp. 789-795

\title{
Preliminary Results on the Use of an Antiserum to Human Parathyrin in a Homologous Radioimmunoassay ${ }^{1}$ )
}

By W. G. Wood ${ }^{2}$ )

Laboratorien für Klinische Chemie und Endokrinologie (Leiter: Prof. Dr. P. C. Scriba)

Medizinische Klinik Innenstadt der Universität München, D-8000 München 2

Rosemarie Butz

Abteilung für Klinische Endokrinologie (Direktor: Prof. Dr. A. von zur Mühlen)

Medizinische Hochschule Hannover, D-3000 Hannover 61

Monika Casaretto

Deutsches Wollforschungsinstitut Veltmanplatz 1, D-5100 Aachen

\section{R. Hehrmann}

Medizinische Klinik C der Universität Düsseldorf (Direktor: Prof. Dr. H. L. Krüskemper) D-4000 Düsseldorf 1

\section{H. Jüppner}

Abteilung für Klinische Endokrinologie (Direktor: Prof. Dr. A. von zur Mühlen)

Medizinische Hochschule Hannover, D-3000 Hannover 61

\section{Marschner, Christine Wachter}

Laboratorien für Klinische Chemie und Endokrinologie (Leiter: Prof. Dr. P. C. Scriba)

Medizinische Klinik Innenstadt der Universität München, D-8000 München 2

H. Zahn

Deutsches Wollforschungsinstitut Veltmannplatz 1, D-5100 Aachen and

R. D. Hesch

Abteilung für Klinische Endokrinologie (Direktor: Prof. Dr. A. von zur Mühlen)

Medizinische Hochschule Hannover, D-3000 Hannover 61

(Received March 31, 1980)

Summary: A new antiserum (Ab Giselle) raised in sheep against extracted human parathyrin was evaluated and compared with an established antiserum (Ab S-47̈8 VI) under several test conditions.

The assay system contained an extracted 1-84 human parathyrin standard and a 1-84 bovine parathyrin tracer. The total assay time was $24 \mathrm{~h}$ and the main assay characteristics as follows:

$\mathrm{B}_{0} / \mathrm{T} 0.28 \pm 0.02$ and $50 \%$ intercept $553 \pm 47 \mathrm{U} \cdot 1^{-1}$. The corresponding data for $\mathrm{Ab} \mathrm{S}-478 \mathrm{VI}$ were:

$\mathrm{B}_{0} / \mathrm{T} 0.23 \pm 0.02$ and $50 \%$ intercept $890 \pm 142 \mathrm{U} \cdot 1^{-1}$.

The normal range in 152 normocalcaemic volunteers (age range 16-67 years) was $10.6-423 \mathrm{U} \cdot 1^{-1}$ (where 1 vial MRC reference preparation $75 / 549$ for human parathyrin = $25 \mathrm{U}$ ), compared with $0-300 \mathrm{U} \cdot \mathrm{l}^{-1}$ for Ab S-478 VI.

1) This work was supported in part by the following grants: Deutsche Forschungsgemeinschaft He 593/11 and BMFT (Bundesministerium für Forschung und Technologie) D-5300 Bonn 12, FRG.

2) New address: Klinik für Innere Medizin, Medizinische Hochschule Lübeck, D-2400 Lübeck 1. 
With the new antiserum, differentiation between hypoparathyroid patients and those with normal function was often possible, and differentiation between normal and elevated levels, as in hyperparathyrinaemia, was very good.

Correlation between Ab Giselle and Ab S-478 VI in 80 normal volunteers was positive $(r=0.450, p=0.01)$ although the regression line showed that the antisera had different specificities (data for the regression line $y=a+b x, a=0.13$, $b=0.55$ ).

Under the assay conditions, the association constant for $\mathrm{Ab}$ Giselle was $0.41 \times 10^{14} 1 \cdot \mathrm{mol}^{-1}$ in contrast to $\mathrm{Ab} \mathrm{S} 478 \mathrm{VI}$ which had a $\mathrm{K}_{\mathrm{a}}$ of $0.53 \times 10^{10} 1 \cdot \mathrm{mol}^{-1}$ under identical conditions. Assays using Ab Giselle could be performed at room temperature, whereas those using Ab S-478 VI performed best at $0{ }^{\circ} \mathrm{C}$.

Preliminary results suggest that $\mathrm{Ab}$ Giselle is better for the routine assay of human parathyrin in serum than Ab S-478 VI, especially in the case of hypoparathyroid patients.

\section{Erste Ergebnisse mit einem Antiserum gegen Parathyrin vom Menschen für einen homologen Radioimmunassay}

Zusammenfassung: Es wurde ein neues Schafsantiserum (Ab Giselle) gegen extrahiertes Human-Parathyrin gewonnen, charakterisiert und mit einem etablierten Antiserum ( $\mathrm{Ab}$ S-478 VI) verglichen. Im Radioimmunoassay wird ein extrahierter 1-84 Human-Parathyrin-Standard und ein boviner Tracer eingesetzt. Die Gesamtdauer der Assays ist 24 Stunden mit folgenden Charakteristiken:

$\mathrm{B}_{0} / \mathrm{T}=0,28 \pm 0,02,50 \%$ Intercept $553 \pm 47 \mathrm{U} \cdot 1^{-1}$. Die entsprechenden Daten für Ab S-478 VI sind:

$\mathrm{B}_{0} / \mathrm{T} 0,23 \pm 0,02,50 \%$ Intercept $890 \pm 142 \mathrm{U} \cdot 1^{-1}$.

Der Normalbereich, gemessen in 152 normalcalcämischen Probanden im Alter zwischen 16 und 67 Jahren lag (2 s-Bereich) zwischen 10,6 und $423 \mathrm{U} \cdot \mathrm{l}^{-1}$ (standardisiert gegen MRC reference preparation 75/549,1 Ampulle $=25 \mathrm{U}$ Human-Parathyrin).

Für Ab S-478 VI lag der Normalbereich für die gleichen Probanden bei 0 bis $300 \mathrm{U} \cdot 1^{-1}$.

Mit dem neuen Antiserum war es häufig möglich, zwischen Patienten mit Nebenschilddrüsen-Unterfunktion und Gesunden zu unterscheiden. Nur 9\% der Patienten mit primärem Hyperparathyreoidismus hatten Parathyrinkonzentrationen im Normbereich.

Es bestand eine positive, wenn auch schwache Korrelation im Normalbereich zwischen den mit Ab-Giselle und Ab S-478 VI gewonnenen Werten $(r=0,450, p=0,01)$, die Regressionskurve zeigt jedoch, daß die beiden Antiseren eine unterschiedliche Spezifität haben (Daten für die Regressionsgerade $y=a+b x, a=0,13, b=0,55$ ).

Unter Assay-Bedingungen liegt die Assoziationskonstante $\left(\mathrm{K}_{\mathrm{a}}\right)$ für Ab-Giselle bei $0,41 \cdot 10^{14} \mathrm{l} \cdot \mathrm{mol}^{-1}$, für $\mathrm{Ab} \mathrm{S}-478 \mathrm{VI}$ bei $0,53 \cdot 10^{10} 1 \cdot \mathrm{mol}^{-1}$. Das Temperaturoptimum für Ab-Giselle liegt bei etwa $7^{\circ} \mathrm{C}$, für Ab S-478 VI bei $0{ }^{\circ} \mathrm{C}$.

Unsere bisherigen Daten lassen Ab-Giselle für die Routinebestimmung von Human-Parathyrin im Serum geeigneter erscheinen als Ab S-478 VI, besonders für die Unterscheidung zwischen gesunden und hyperparathyreoten Patienten.

\section{Introduction}

The measurement of human parathyrin has presented problems in many laboratories, mainly because of the low quality of antisera and tracer, not to mention material for standards. During the past.few years, antisera and standards have been prepared using extracted human parathyrin, either from parathyroid adenomata or from cell culture media. The assay described here uses human standards, an antiserum raised against human parathyrin and a bovine parathyrin tracer. The results were compared with a system, which has been used since 1977 for the analysis of over 5000 sera, and in which the antiserum used was raised to a mixture of bovine and porcine parathyrin (Ab S-478 VI). The properties of S $478 \mathrm{VI}$ have been well documented
$(1-4)$. The new antiserum (Ab Giselle) appears to have better properties in differentiating between hypo-, normo- and hyperparathyroid patients.

\section{Materials and Methods}

Antisera were raised in sheep by two of the authors (R. H. and R. D. H.) against a mixture of bovine and porcine parathyrin (Ab S-478 VI) and against extracted human parathy rin (Ab Giselle).

Material for tracer was purchased from Inolex (Chicago, USA) and was stated to be 1-84 bovine parathyrin. The lot No. used for all tracer preparations was $1515-\mathrm{C} 001$.

Material for standards was either extracted from human parathyroid adenomata purified and calibrated against MRC 75/549 human parathyrin 1-84 reference preparation, or extracted from the media of preparations of human parathyroid adenoma 
cell cultures, purified and calibrated as above. This material was coded "P 2 " and is 1-84 human parathyrin (5).

lodine for labelling was obtained from Amersham-Buchler (Braunschweig, FRG). Donkey-anti-sheep serum was obtained from Technia (London, GB) and was used at an initial dilution of $1: 12$.

Tracer was prepared using the solid-phase Iodogen method already described (6) followed by a desalting step using Sephadex SP-C $25(6)$ and further purification over a $130 \times 2.5 \mathrm{~cm}$ Ultrogel AcA 54 column (2).

Standards were prepared in parathyrin-free serum (2) covering the range $0-20.000 \mathrm{U} \cdot$ liter $^{-1}$ human parathyrin. The assays were coded and carried out as described in table 1.

Assay S-478 50P was carried out in $0.05 \mathrm{~mol} / 1$ Tris buffer $\mathrm{pH} 8.0$ containing $2.5 \mathrm{~g} \cdot$ liter $^{-1}$ gelatin and assay G-50 DAB in the same buffer, but with bovine serum albumin in place of the gelatin.

Experiments to determine the antibody specificity were carried out as described (1). Human parathyrin-fragments $1-34$ 44-68 and 53-84 together with bovine parathyrin-fragments 28-48 were generously donated by Dr.M. Rosenblatt, Boston, USA. Human parathyrin-fragment $32-43$ is the first peptide obtained from a programme undertaken to synthesise human parathyrin by three of the authors (H. Z., M. C. and R. D. H.).

\section{Results}

\section{Kinetic studies}

The kinetics of tracer binding to Ab S478 VI have already been published (7) and those for Ab Giselle are shown in figure 1 . The kinetics cover a $6 \mathrm{~h}$ period for three situations, namely $B_{0}$, with serum $D 8$ which lies on the upper limit of the normal range, and for the unspecific binding (UB). The studies have been carried out at ambient temperature $\left(21^{\circ} \mathrm{C}\right)$, in a refrigerator $\left(7^{\circ} \mathrm{C}\right)$ and in an ice-bath $\left(0^{\circ} \mathrm{C}\right)$. No preincubation was performed. The results show that a preincubation is preferable, as serum D8 and the $B_{0}$ (zero standard in parathyrin-free serum) run together in this study. Optimal conditions for tracer binding are around

Tab. 1. Comparison of the assays using Ab S-478 VI and $\mathrm{Ab}$ Giselle.

\section{Ab S-478 VI -}

Assay code $S=47850 P$

$50 \mu l$ serum or standard

$100 \mu \mathrm{l} \mathrm{Ab} \mathrm{S}=47.8 \mathrm{VI}$

(initial dilution 1:2400)

$18 \mathrm{~h}$ incubation $4^{\circ} \mathrm{C}$

(cọld room)

$50 \mu \mathrm{l}$ tracer (ca. $170 \mathrm{~Bq}$ )

$6 \mathrm{~h}$ incubation in an ice bath

$50 \mu l$ carrier serum

$1000 \mu l$ polyethylene glycol $\left(150 \mathrm{~g} \cdot\right.$ liter $\left.^{-1}\right)$

Vortex, centrifuge at $2000 \dot{g}$ for $10 \mathrm{~min}$, aspirate off supernatant, count for $2-3 \mathrm{~min}$ in a $\gamma$-counter
Ab Giselle -

Assay code G-50 DAB

$50 \mu \mathrm{l}$ serum or standard

$100 \mu \mathrm{l} \mathrm{Ab}$ Giselle (initial dilution 1:7500)

$18 \mathrm{~h}$ incubation $4-10^{\circ} \mathrm{C}$ (normal refrigerator)

$50 \mu$ tracer (ca. $170 \mathrm{~Bq}$ )

$6 \mathrm{~h}$ incubation $4-10^{\circ} \mathrm{C}$ $50 \mu$ l sheep $\gamma$-globulin $(7 \mu \mathrm{g})$

$100 \mu 1$ Donkey-anti-sheep serum (1:12 dilution) $1000 \mu 1$ polyethylene glycol $\left(60 \cdot \mathrm{g}^{-1}\right.$ liter $^{-1}$ )

Let stand at $4-10^{\circ} \mathrm{C}$ for $15 \mathrm{~min}$, then follow same procedure as for assay S-478 50P

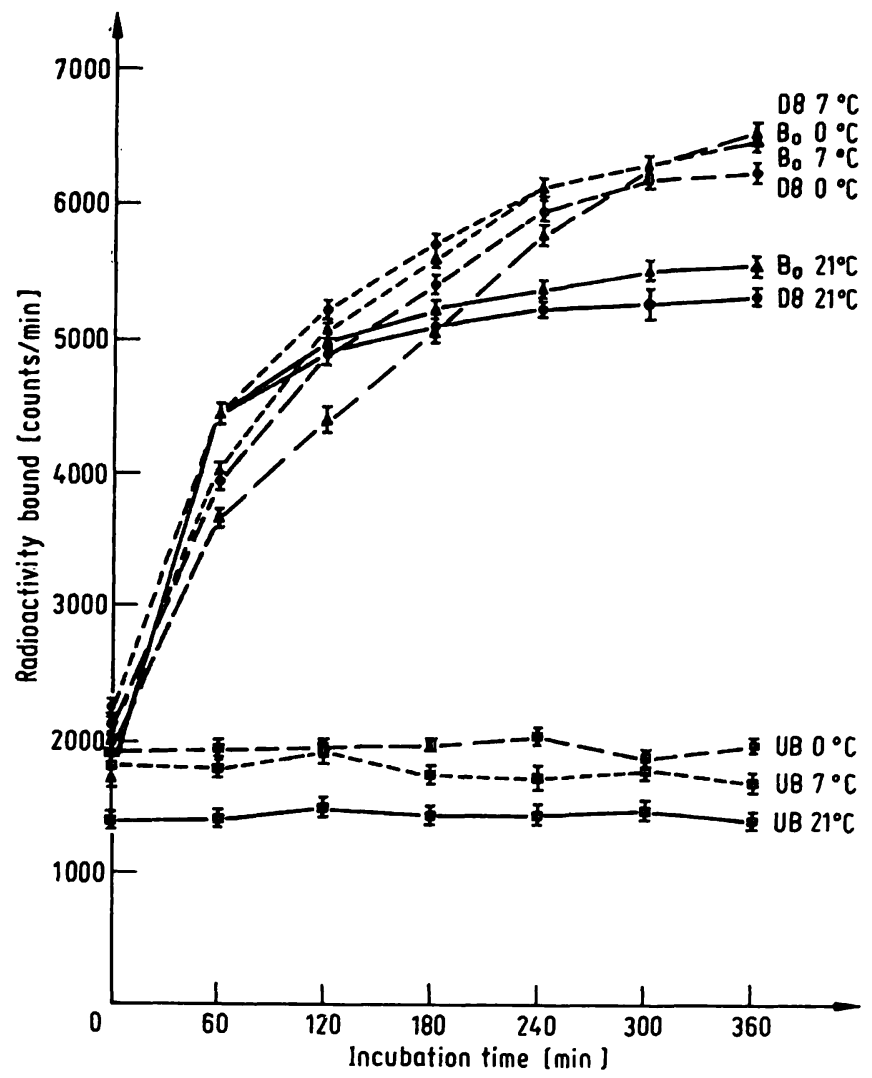

Fig. 1. Kinetic studies using Ab Giselle. Studies at 3 temperatures and 3 concentrations - zero standard $\left(B_{0}\right)$ control serum on the upper limit of the normal range (D8) and unspecific binding (UB). Tracer: bovine 1-84 parathyrin, 23000 counts/min.

$6 \mathrm{~h}$ at $7^{\circ} \mathrm{C}$ - this means that the assay can be run in a normal refrigerator. The affinity constants for the antisera under the conditions shown in table 1 were for $\mathrm{Ab}$ Giselle $0.41 \times 10^{14} 1 \cdot \mathrm{mol}^{-1}$ and for Ab S-478 VI $0.53 \times 10^{10} 1 \cdot \mathrm{mol}^{-1}$.

\section{Antibody specificity}

The specificity of $\mathrm{Ab} \mathrm{S}-478 \mathrm{VI}$ has already been published (1-3), and Ab Giselle is shown in figure 2. When 1.84 bovine $\left[{ }^{125} \mathrm{I}\right]$ parathyrin is used as tracer it can be seen that $\mathrm{Ab}$ Giselle has the highest affinity for the mid regional fragment 44-68 human parathyrin. Affinity constants $\left(\mathrm{K}_{\mathrm{a}}\right)$ for intact human parathyrin were found to be $0.56 \times 10^{15} 1 \cdot \mathrm{mol}^{-1}$ and for the 44-68 human parathyrin fragment $2 \times 10^{15} \mathrm{l} \cdot \mathrm{mol}^{-1}$ using an 4-day assay as described (1). Ab S-478 VI, in contrast, recognised these peptides with equal affinity $\left(\mathrm{K}_{\mathrm{a}} 0.6 \times 10^{13} 1 \cdot \mathrm{mol}^{-1}\right)$ under identical assay conditions. Ab Giselle, which resembles Ab S-469 (1) in its specificity, does not react with 53-84 human parathyrin, 1-34 human parathyrin or 32-43 human parathyrin and only reacts poorly with $28-48$ bovine parathyrin, showing that the Ab-determinants start around amino-acids 44-48. 


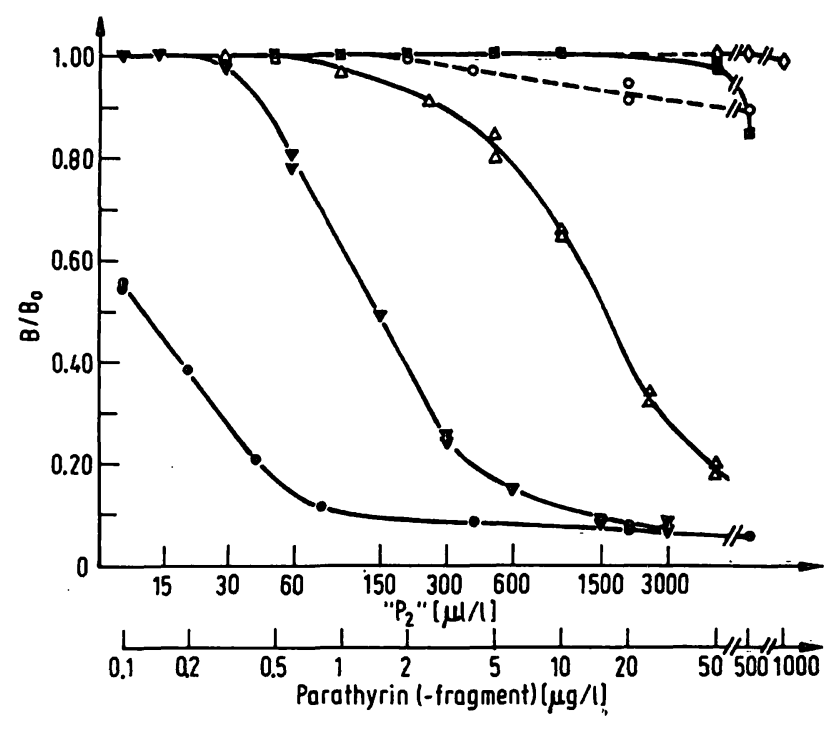

Fig. 2. Specificity of $A b$ Giselle to different human parathyrin and bovine parathyrin fragments as well as 1-84 human parathyrin. $\diamond--\diamond$ bovine, 28-48 $\square-\square$ human, 1-34 ○--o human, 53-84 $\Delta-\Delta$ human, 75/549 $\Delta-\Delta$ human, "P," $P_{2}-\bullet$ human, 44-68. All studies used bovine $\left[{ }^{125}\right.$ I] parathy rin (1-84) tracer and an assay time of 4 days (1).

Tab. 2. Quality control parameters for assays G-50 DAB and S-478 50P.

\section{Control sera}

a) Assay G-50 DAB

$$
\begin{aligned}
& \text { Parathyrin } \\
& \text { mean } \\
& \left(U \cdot \text { liter }^{-1}\right)
\end{aligned}
$$

S.D. $\left(U \cdot\right.$ liter $\left.^{-1}\right)$

C. V.

$$
23.3
$$

405
440

2197

4019

KN2

K18

$\mathrm{D} 8$

b) Assay S-478 50P

$\begin{array}{lc}\text { K18 } & 90.8 \\ \text { P2a } & 146 \\ \text { D8 } & 450 \\ \text { P7P } & 3391 \\ \text { KN2 } & 4995\end{array}$

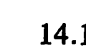

65.8

59.8

345

808

30.6
23.8
66.6
789
1779

1779
2. Curve parameters .

a) Assay G-50 DAB

$\mathrm{B}_{0} / \mathrm{T} 0.288 \pm 0.021-$ C. V. $7.46 \%$

$50 \%$ intercept $553 \pm 47 \mathrm{U} \cdot$ liter $^{-1}$ - C. V. $8.51 \%$

b) Assay S-478 50P

$\mathrm{B}_{0} / \mathrm{T} 0.230 \pm 0.018-\mathrm{C} . \mathrm{V} .7 .71 \%$

$50 \%$ intercept $890 \pm 142 \mathrm{U} \cdot$ liter $^{-1}$ - C. V. $15.9 \%$

Data from 18 assays for G-50 DAB and from 16 assays for S-478 50P.

\section{Quality control parameters in both assays}

Table 2 shows the inter-assay coefficients of variation (C. V.) of 5 control sera and the variation of the tracer binding (expressed as $\mathrm{B}_{0} / \mathrm{T}$ ) and the $50 \%$ intercept of the standard curve. The results are from 18 G-50 DAB and $16 \mathrm{~S}-478$ 50P assays. The control sera are from defined patient groups, namely: $\mathrm{K} 18$ is an outdated blood plasma sample, P2a a pooled serum from normal levels in the S-478 50P assay, D8 a pooled serum from patients undergoing digoxin therapy, P7P a pooled serum from patients with primary hyperparathyrinaemia, and $\mathrm{KN} 2$ a serum from patients with secondary hyperparathyrinaemia. Typical standard curves are shown in figure 3 in which the same tracer and standards were used. Both assays were carried out simultaneously. The C. V. show the typical U-form of the concentration dependence of the precision profile.

\section{Normal range}

Figure 4 shows the distribution of 152 normocalcaemic volunteers measured in the G-50 DAB assay and of 118 normals in the S 478 50P assay.

The $95 \%$ confidence limits of the G-50 DAB assay were 10.6-423 U $\cdot$ liter $^{-1}$ and 0-234 $\mathrm{U}^{-}$liter $^{-1}$ for the S478 50P assay. Although the distribution of values was slightly skewed in each case, it did not differ significantly from a normal Gaussian curve.

Figure 5 shows the distribution of 88 sera measured at the same time in both assay systems with S-478 50P on the $\mathrm{X}$-axis. The correlation was significant $(r=0.450$, $p=0.01$ ) although it is plain to see that the two antisera have different specificities, as shown by the intercept of $130 \mathrm{U} \cdot$ liter $^{-1}$ and slope of 0.55 . The lines AC and BC enclose the normal range of both assays and the lines

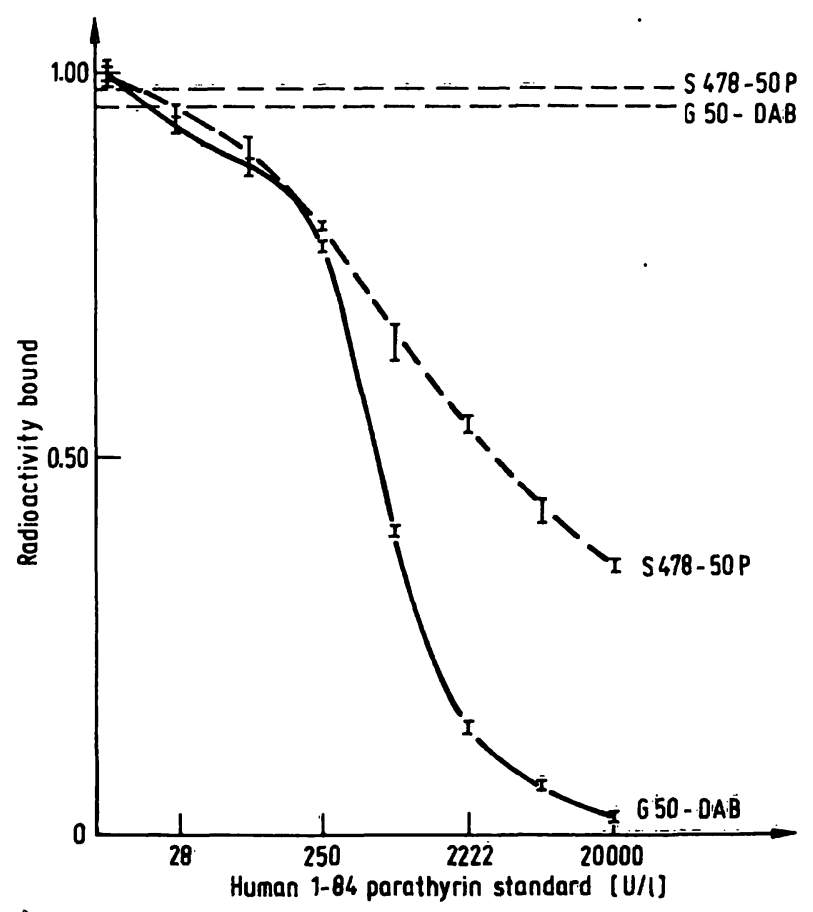

Fig. 3. Typical standard curves for human 1-84 parathyrin standard using Ab S-478 VI (S 478-50 P) and Ab Giselle (G 50-DAB). The dotted lines show the lower limit of detection (zero - 3 s.value on the curve): 


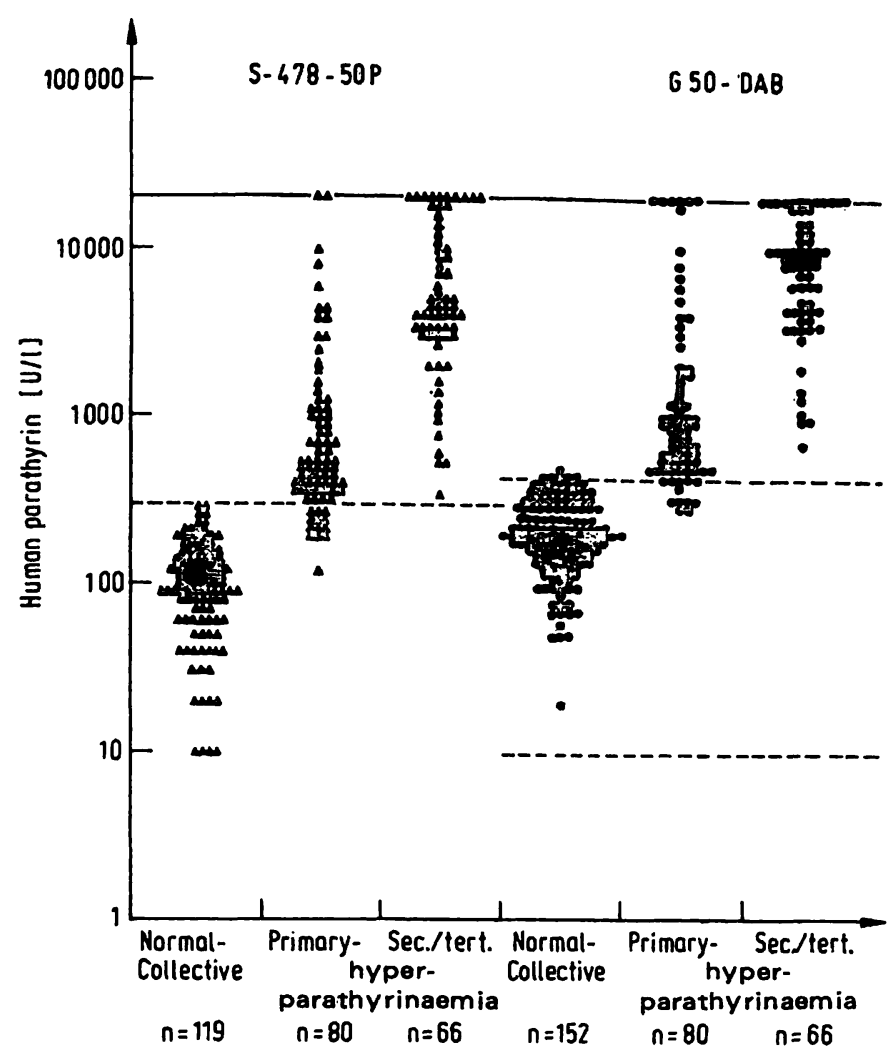

Fig. 4. Scattergram showing normal volunteers, patients with primary, secondary and tertiary hyperparathyrinaemia. Values $>20000 \mathrm{U} \cdot$ liter $^{-1}$ are shown as being equal to the upper standard. S 478-50P = Antibody Ab S-478 VI G 50-DAB = Antibody Giselle - - Limits of normal range Level of highest standard.

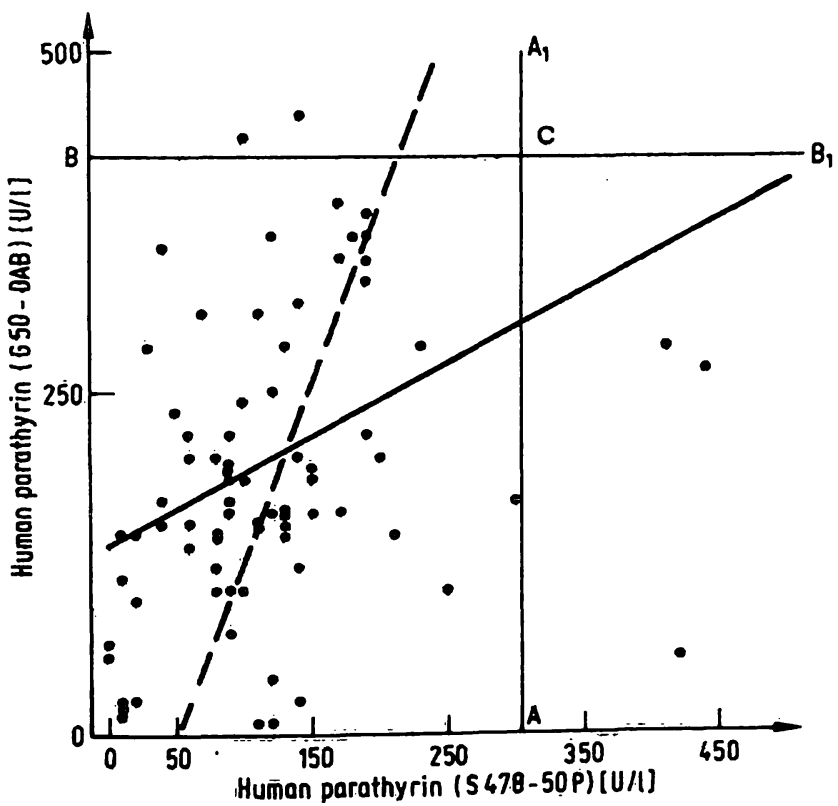

Fig. 5. Correlation study on 88 normal sera measured in both assays simultaneously. Regression data for the equation $y=a+b x: a_{y x}=130 ; b_{y x}=0.55$; for the equation $x=a+b y: a_{x y}=57 ; b_{x y}=0.36$. Correlation coefficient $\mathrm{r}=\mathbf{0 . 4 5 0 .}$.

$A_{1} C$ and $B_{1} C$ enclose the space in which values are pathological in both assays. The values enclosed by the lines $A_{1} C B$ are normal in the S-478 50P assay, but pathological in the G-50 DAB assay $(n=2)$; those enclosed by the lines $\mathrm{ACB}_{1}$ are norm $\mathrm{a}^{1}$ in the G-50 DAB assay and pathological in the $S-47850 P$ assay $(n=5)$. Regression data for $a_{x y}$ and $b_{x y}$ are given (regression line --) as well as for $a_{y x}$ and $b_{y x}$ (regression line -).

\section{Patients with hyperparathyrinaemia}

Figure 3 shows the distribution of 80 patients with surgically confirmed primary (extra-renal) hyperparathyrinaemia as well as 66 patients with either secondary (renal) hyperparathyrinaemia or tertiary (autonomousrenal) hyperparathyrinaemia measured in both assay systems. Using a non-parametric test (Wilcoxon-RankTest) both assays were able to differentiate between normo- and primary hyperparathyrinaemia, assay G-50 DAB with a significance $p<0.001$ and S-478 50P with a significance of $p<0.01$.

\section{Comparison of miscellaneous cases of interest}

Table 3 shows ten cases where the clinician requested serum parathyrin levels to aid him in his diagnosis. Three cases are shown in patients undergoing total parathyroidectomy with reimplantation of parathyroid tissue in the right forearm (8). Case 5903 shows up to 21 day post operative control of peripheral parathyrin levels. Case 5919 shows a non-functioning graft in a patient operated on for tertiary hyperparathyrinaemia, and case 5668, a functioning graft in a patient, also operated on for tertiary hyperparathyrinaemia. Case 5801 shows a patient with primary hyperparathyrinaemia who showed suppression of parathyrin after a calcium infusion (9). The values for levels of serum calcium, phosphorus and creatinine are shown. From 10 patients who had undergone total parathyroidectomy without subsequent reimplantation of glandular tissue, 9 had parathyrin levels which were not significantly different from the zero-standard.

\section{Compärison of neck-vein catheters in two patients with recurrent primary hyperparathyrinaemia}

Two patients with recurrent primary hyperparathyrinaemia were catheterised to localise the parathyroid adenoma. The sera were measured in both assay systems and gave interesting results. In one patient, although the numerical values were different, the ratio between the values was more or less constant (G-50 DAB: $\mathrm{S}-47850 \mathrm{P}-2.38 \pm 0.44: 1, \mathrm{n}=12$, range $1.77-3.13: 1$ ). All 13 values were grossly elevated in both assays (G-50 DAB $7400->20000 \mathrm{U} \cdot$ liter $^{-1}-\mathrm{S}-478$ 50P $3300->20000 \mathrm{U} \cdot$ liter $^{-1}$ ).

In a second patient, the results varied widely, being far better in the G-50 DAB assay, where the adenoma was easily localised. Here the ratio of the parathyrin levels expressed as G-50 DAB : S-478 50P varied between 0.79:1 
Tab. 3. Miscellaneous cases of interest. Sera measured in both assay systems.

\begin{tabular}{|c|c|c|c|c|c|c|}
\hline Case No. & Relevant details & $\begin{array}{l}\text { Parathyrin } \\
\text { G-50 DAB } \\
\left(U \cdot \text { liter }^{-1}\right)\end{array}$ & $\begin{array}{l}S-47850 P \\
\left(U \cdot 1 \text { liter }{ }^{-1}\right)\end{array}$ & $\begin{array}{l}\text { Serum-Ca } \\
\left(\mathrm{mmol} \cdot \mathrm{l}^{-1}\right)\end{array}$ & $\begin{array}{l}\text { Serum-P } \\
\left(\mathrm{mmol} \cdot \Gamma^{-1}\right)\end{array}$ & $\begin{array}{l}\text { Serum- } \\
\text { Creatinine } \\
\left(\mu \mathrm{mol} \cdot \mathrm{l}^{-1}\right)\end{array}$ \\
\hline 5562 & Hypophosphataemia & 290 & 90 & 2.22 & 0.56 & 80.0 \\
\hline 5596 & Renal stones (Ca-oxalate) & 332 & 210 & 2.41 & 0.83 & 97.0 \\
\hline 5916 & Transient hypercalcaemia (Ca $2.4-2.8 \mathrm{mmol} \cdot \mathrm{l}^{-1}$ ) & 81 & 132 & $2.55^{:}$ & 1.38 & 62.5 \\
\hline 5850 & Shock + hypocalcaemia & 1490 & 1650 & 2.11 & 1.65 & 264 \\
\hline 5833 & Persistent hypercalcaemia & 300 & 161 & 2.58 & 0.87 & 88.3 \\
\hline 5929 & Hypercalcaemia with changes in bone density & 460 & 100 & 2.65 & 1.24 & 51.1 \\
\hline 5801 & $\begin{array}{r}\text { Primary hyperparathyrinaemia } \\
- \text { before } \mathrm{Ca} \text { infusion } \\
\text { - after } \mathrm{Ca} \text { infusion }\end{array}$ & $\begin{array}{r}5100 \\
871\end{array}$ & $\begin{array}{r}4330 \\
890\end{array}$ & $\begin{array}{l}2.85 \\
3.40\end{array}$ & $\begin{array}{l}0.81 \\
0.99\end{array}$ & $\begin{array}{l}52.8 \\
56.9\end{array}$ \\
\hline 5919 & $\begin{array}{l}\text { Parathyroid gland in lower right arm function test } \\
\text { Blood from right arm } \\
\text { Blood from left arm } \\
\text { (control made } 3 \text { day post-operatively) }\end{array}$ & $\begin{array}{l}260 \\
290\end{array}$ & $\begin{array}{l}190 \\
190\end{array}$ & $\begin{array}{l}2.00 \\
2.01\end{array}$ & $\begin{array}{l}2.10 \\
2.09\end{array}$ & $\begin{array}{l}1090 \\
1100\end{array}$ \\
\hline 5668 & $\begin{array}{c}\text { As case } 5919 \text { above. } \begin{array}{l}\text { Blood from right arm } \\
\text { Blood from left arm }\end{array} \\
\text { (control made } 7 \text { day post-operatively) }\end{array}$ & $\begin{array}{r}1170 \\
472\end{array}$ & $\begin{array}{l}811 \\
411\end{array}$ & $\begin{array}{l}2.01 \\
1.98\end{array}$ & $\begin{array}{l}2.17 \\
2.23\end{array}$ & $\begin{array}{l}493 \\
501\end{array}$ \\
\hline 5903 & $\begin{array}{l}\text { Parathyroid gland transplant in lower right arm - } \\
\text { post operatively follow-up for function. } \\
\text { Blood from right arm } \\
1 \text { day postoperatively } \\
2 \text { days postoperatively } \\
3 \text { days postoperatively Ca-substitution } \\
7 \text { days postoperatively } \\
10 \text { days postoperatively } \\
21 \text { days postoperatively (Graft functioning, } \\
\\
\text { Ca-substitution reduced) }\end{array}$ & $\begin{array}{r}40 \\
62 \\
60 \\
70 \\
44 \\
269\end{array}$ & $\begin{array}{r}90 \\
62 \\
90 \\
122 \\
101 \\
247\end{array}$ & $\begin{array}{l}2.15 \\
2.21 \\
2.15 \\
1.65 \\
1.82 \\
1.99\end{array}$ & $\begin{array}{l}1.24 \\
1.57 \\
1.63 \\
1.59 \\
1.82 \\
2.44\end{array}$ & $\begin{array}{l}259 \\
255 \\
263 \\
255 \\
277 \\
284\end{array}$ \\
\hline
\end{tabular}

and $7.03: 1$. The range of levels for G-50 DAB was 371-3520 U $\cdot$ liter $^{-1}$ and for S-478 50P 133-671 U . $\operatorname{liter}^{-1}$. The results from the second catheter emphasize the differing specificity of the antisera.

\section{Discussion}

The determination of human parathyrin by radioimmunoassay has lost its "exclusiveness" now that sufficient amounts of appropriate antisera cross-reacting with human parathyrin $(2,3)$ are available. Nevertheless most assays are based on the use of heterologous materials. There is still a need for human parathyrin as radioactive tracer and for antisera raised against distinct human parathyrin fragments, as parathyrin does not circulate in blood as single hormone but as several peptide fragments. The physiological and clinical importance of such fragments is beginning to be understood (10). In this respect only assay systems using well characterized antisera will be valid in interpreting deviations from the physiological circulating peptide pattern.

The difference in specificity of the antisera described here is shown by the results from control serum $\mathrm{P} 2 \mathrm{a}$ and the catheter studies. It appears that $\mathrm{Ab} \mathrm{S}-478 \mathrm{VI}$ sees more of the intact 1-84 human parathyrin. This corresponds to the characterization of the antiserum by intact human parathyrin and its fragments $(2,3)$.
The study of specificity for $\mathrm{Ab}$ Giselle reveals that it sees more of the peptides in the 44-68 region of the human parathyrin molecule. Neither antisera recognises extreme $\mathrm{N}$ - or extreme $\mathrm{C}$-regions of human parathyrin. The wide experience using mid-regional specific antisera has demonstrated that such antisera are extremely useful for the detection of an overall overproduction of parathyrin peptides associated with the common clinical form of renal and extrarenal hyperparathyrinaemia. It appears that there may be a species difference in the type of antisera produced to human parathyrin. All four antisera raised by two of the authors (R. H. and R. D. H.) in sheep (S 478, S 469, Giselle, Claudine) show a specificity predominantly for the mid-region of the molecule. This is also true for the antibodies raised in goats (personal communication Prof. $R$. Ziegler, Heidelberg). In contrast, antibodies raised in guinea pigs show more $\mathrm{N}$ - and/or $\mathrm{C}$-terminal specificity. To investigate these observations further, the metabolic processes involved in degrading parathyrin must be studied in different species. When this has been done, perhaps the required specificity'of an antiserum for specific peptide sequences can be predicted, depending upon which animal is used for raising the antisera. The results of such a study could be of utmost importance in the choice of cells to use in the production of monoclonal antisera. 
The advantage of the G-50 DAB assay using Ab Giselle is that the standard curve is steeper and does not level off at $\mathrm{B} / \mathrm{B}_{0}$ of ca. $30 \%$. In addition, the $50 \%$ intercept lies considerably closer to the normal range than in the case of Ab S478 VI. The fact that the Ab Giselle is raised against extracted human parathyrin is important as it brings the establishment of a truely homologous human parathyrin assay with human parathyrin tracer one step closer. Ab Giselle is much less sensitive to temperature than $\mathrm{Ab} \mathrm{S}-478 \mathrm{VI}$, thus making the assay conditions somewhat easier. In the assay S 478 50P, all reagents must be added at $0{ }^{\circ} \mathrm{C}$, and the second (tracer) incubation must be carried out in an ice bath. Failure to do this results in a difference of binding in the zero standard of up to $20 \%$ inside $10 \mathrm{~min}$ when left to stand at room temperature after the tracer incubation. The difference in performance is reflected in the affinity constants $\left(\mathrm{K}_{\mathrm{a}}\right)$ of both antibodies under assay conditions. The $\mathrm{K}_{\mathrm{a}}$ for $\mathrm{S}-478 \mathrm{VI}$ is $0.53 \cdot 10^{10} 1 \cdot \mathrm{mol}^{-1}$, whereas that for $\mathrm{Ab}$ Giselle is $0.41 \cdot 10^{14} \mathrm{l} \cdot \mathrm{mol}^{-1}$ for the assay run at $7^{\circ} \mathrm{C}$ ! Figure 1 shows indirectly that $\mathrm{Ab}$ Giselle binds the tracer more rapidly than the human parathyrin found in serum, thus making a preincubation step necessary. The quality-control parameters show the stability of the assay system using the new antiserum.
The fact that 9 from 10 hypoparathyroid patients had levels below the normal range is encouraging, because many antisera in current use are unable to differentiate between normals and hypoparathyroid patients.

The clinical interpretation of the results from both assays are mostly similar, but there are cases in which different answers are given. These differences are not yet fully understood. As the parathyrin result is usually used to confirm a clinical diagnosis, then the differences in the values given by both assays must be seen in conjunction with other parameters such as serum calcium, phosphorus, creatinine and alkaline phosphatase, although they cannot yet be related to specific clinical symptoms. Taking this into consideration the so-called normal parathyrin levels in the hands of clinicians specialising in calcium metabolism disturbances take on a new meaning. To conclude, this study has demonstrated that a new antiserum to human parathyrin has proved to be useful in the clinical diagnosis of calcium metabolism disorders involving the parathyroid glands, as well as making the laboratory determination of serum human parathyrin easier and quicker to carry out. At the same time the quality of the assay is improved by introducing a double-antibody polymer enhanced separation of bound and free antigen.

\section{References}

1. Hehrmann, R., Wilke, R., Nordmeyer, J. P. \& Hesch, R. D. (1976), Dtsch. Med. Wochenschr. 101, 1726-1729.

2. Wood, W. G., Marschner, I. \& Scriba, P. C. (1979), Horm. Met. Res. 11, 309-317.

3. Hehrmann, R., Nordmeyer, J. P., Wilke, R. \& Hesch, R. D. (1980), Acta Endocrinol. (Kbh.) in print.

4. Hehrmann, R., Nordmeyer, J. P., Mohr, H. \& Hesch, R. D. (1980), J. Immunoassay, in print.

5. Dorn, G., Montz, R., Mohr, H., Dietel, M. (1979), Acta Endocrinol. (Kbh.) Suppl. 225, Abstr. 403.

6. Wood, W. G., Wachter, Chr. \& Scriba, P. C. (1980), Fresenius Z. Anal. Chem. 301, 119.
7. Wood, W. G., Marschner, I. \& Scriba, P. C. (1978), In: Radioaktive Isotopen in Klinik und Forschung, 13. Band (R. Höfer, ed.) Verlag H. Egermann, Wien, Teil 1, pp. 479488.

8. Spelsberg, F., Oettinger, W., Marschner, I. \& Wood, W. G. (1980), Münch. Med. Wochenschr. 122, 873-874.

9. Murray, T. M., Peacock, M., Powell, D., Monchik, J. M. \& Potts, J. T., jr. (1972), Clin. Endocrinol. 1, 235-246.

10. Hesch, R. D. \& Hehrmann, R. (1979), Verhdlg. Dtsch. Ges. Inn. Med. 85, 288-298.

Dr. W. G. Wood

Klinik für Innere Medizin Medizinische Hochschule Lübeck Ratzeburger Allee 160

D-2400 Lübeck 1 
